実環境においてロボットが行動する時に連続值行動で表現する事が適切である様な場合には actor-critic 手法が利用できることが知られている．本研究では LEGO MINDSTORMS を用い複数の自律ロボットに よるシーソーバランシング閭題を解決する協調行動獲得についての実験について報告する.

\title{
2P1-3F-B5 遠隔制御を伴う自律除雪機の構築に関する基礎研究
}

○佐藤 哲史 (北大)，牧野 勤 (北大), 成瀬 継太郎 (北大), 横井 浩史 (北大)

A Study on Development of the Autonomous Snowplow with Remote Control 嘉数 侑昇 (北大)

Sato T.(Hokkaido Univ.), Makino T.(Hokkaido Univ.) Naruse K.(Hokkaido Univ.), Yokoi H.(Hokkaido Univ.), Kakazu Y.(Hokkaido Univ) 本研究では，自律的に除雪作業を行うことができる除雪機の開発を目的としている，本報告では，除雪 機の遠隔操作を中間目的に設定し，その寒現可能性を検討した。

2P1-3F-B6

バネー筫点系を基本としたロボットモデルにおける動作獲得

一進化型計算による力法とその過程の解析一

○上原 -...寿 (北大), 横井 浩史 (北大), 嘉数 侑昇 (北大) Evolutionary Acquisition of Behavior using Robot Model based on Spring-mass System O Uehara K.(Hokkaido Univ.), Yokoi H.(Hokkaido Univ.), Kakazu Y.(Hokkaido Univ.)

進化ロボティクスにおける形態と機能間の関係を考えるための基礎的な研究として, 動作の進化が示寸 性質を調べる箺験を行った。GA を利用した実験の結果, 適応度関数の設計に応じた異なる動作パターンが 獲得された。

2P1-3F-B7 ラーニングクラシファイアの報酬系再構築による群ロボットシステムの制御

○下正博 (北大), 川上敬 (道工大), 横讲 浩史 (北大), 嘉数 侑昇 (北大) Control of Mob System using by Learning Classifier with Adaptive Reward System

Kinoshita M.(Hokkaido Univ.), Kawakami T.(Hokkaido Inst. of Technology), Yokoi H.(Hokkaido Univ.) Kakazu Y.(Hokkaido Univ.) ラーニングクラシファイアシステムによる群ロボットの行動制御を目的とする.クラシファイアシステ ムでは報酬系の作り方が適用問題におけるタスクの達成に大きく影響寸る。本研究では適态的に報酬系を 切替え，郡ロボットの目標を達成する。

\section{•ロボットの脳を創る 1}

2P1-3F-B8 パターン認識の前処理としての次元圧縮法

西村将臣 (埼玉大), ○平成 和幸 (埼玉大), 溝口博 (東京理科大) 三禹 健稳 (埼玉大), 吉澤 修治 (埼玉大)

Dimensionality Reduction Method as Preprocessing for Pattern Recognition

Nishimura M.(Saitama Univ.), $\bigcirc$ Hiraoka K.(Saitama Univ.) Mizoguchi H.(Tokyo Univ. of Science), Mishima T.(Saitama Univ.), Yoshizawa S.(Saitama Univ.)

高次元データのパターン認識では，前処理として次元圧縮を行うのが一般的である. 次元压縮の代表的 手法は主成分分析だが，それが「認識のための次元厌縮」として良いといら保証はない，本研究では，クラ ス情報を活用寸ることでその改良を試みる。

2P1-3F-C1＼cjkstart視覚フィードバックと自己評価による共同注意の段階的獲得

O森田 章生 (阪大), 長井志江 (阪大), 細田 耕 (阪大/阪大 FRC), 浅田 稔 (服大/阪大 FRC) Incremental Learning of Joint Attention by Visual Feedback and Self Evaluation

Morita A.(Osaka Univ.), Nagai Y.(Osaka Univ.), Hosoda K.(Osaka Univ./HANDAI FRC), Asada M.(Osaka Univ./HANDAI FRC) 本研究では視覚フィードバックと自己評価によってロボットに共同注意の能力を獲得させるメカニズム を提案する. そしてロボットがその能力を外部からの明示的な評価なしに，段階的に獲得することを示す。

2P1-3F-C2 バックラッシュクラッチをもつヒューマノイドの歩行制御

Walking Control for Humanoid with Backlash Clutch ○神崎 秀 (東大), 中村仁彦 (東大), 岡田昌史 (東大) Kanzaki S.(The Univ. of Tokyo), Okada M.(The Univ. of Tokyo), Nakamura Y.(The Univ. of Tokyo)

本研究では, フリー状態と高トルク出力状態の両方を実現する滕関節機構「バックラッシュクラッチ」を もつヒューマノイドを対象とする，機構の従反力性を利用し，環境のダイナミクスと親和性の高い歩行制 御在実現叮る。 